\title{
The effect of selected macrolides on the properties of bovine leukocytes
}

\author{
Renata Urban-Chmiel ${ }^{1 *}$, Andrzej Wernicki ${ }^{1}$, Urszula Lisiecka ${ }^{2}$, \\ Andrzej Puchalski ${ }^{1}$, Marta Dec ${ }^{1}$, Diana Stęgierska ${ }^{1}$, and Lukasz Kurek ${ }^{3}$
}

${ }^{I}$ Sub-Department of Veterinary Prevention and Avian Diseases, Institute of Biological Bases of Animal Diseases, Faculty of Veterinary Medicine, University of Life Sciences, Lublin, Poland

${ }^{2}$ Department of Epizootiology and Clinic of Infectious Diseases, University of Life Sciences, Lublin, Poland

${ }^{3}$ Sub-Department of Internal Diseases of Farm Animals and Horses, University of Life Sciences, Lublin, Poland

\section{URBAN-CHMIEL, R., A. WERNICKI, U. LISIECKA, A. PUCHALSKI, M. DEC, D. STEGIERSKA, L. KUREK: The effect of selected macrolides on the properties of bovine leukocytes. Vet. arhiv 87, 571-584, 2017.}

\section{ABSTRACT}

The aim of the study was to evaluate the effect of tylosin, tilmicosin and roxithromycin on viability, nitro blue tetrazolium reduction (NBT) assay, chemotaxis, apoptosis and oxidative stress in bovine leukocytes in vitro conditions. The material for the study consisted of blood collected into EDTA tubes from the external jugular vein of Holstein-Friesian cattle aged 1 week to 2.5 years, during routine veterinary examinations. In leukocytes the percent of viability, nitrate ion concentration (NO), metabolic activity (NBT, nitrotetrazolium blue reduction assay), chemotactic activity and apoptosis were determined. The results indicated a slight negative effect of these macrolides on the viability of the leukocytes, and confirmed the ability of macrolides to induce apoptosis in leukocytes in vitro. These results indicate that all of the macrolides investigated exhibit a modulatory effect on the functions of leukocytes isolated from cattle of different ages. The strongest inhibitory effect on the NBT reduction assay and chemotaxis of the leukocytes was exhibited by roxithromycin, which at the same time had the least negative effect on the leukocytes.

Key words: apoptosis, bovine leukocytes, macrolides, oxidative stress

\section{Introduction}

Macrolides are bacteriostatic antibiotics which inhibit protein synthesis in the bacterial cell by binding to the 50s ribosomal subunit. At high concentrations they exhibit bactericidal effects on Gram-positive bacteria, mainly of the genus Streptococcus spp.,

\footnotetext{
${ }^{*}$ Corresponding author:

Renata Urban-Chmiel, Sub-Department of Veterinary Prevention and Avian Diseases, Institute of Biological Bases of Animal Diseases, University of Life Sciences, Akademicka 12, 20-033 Lublin, Poland, Phone:+48 81445 6036; Fax: +48 814456032 ; E-mail: renata.urban@up.lublin.pl
} 
as well as some Gram-negative bacteria, e.g. Haemophilus influenzae, Neisseria spp., and Campylobacter spp. Due to the high concentration attained within bacterial cells and phagocytes, macrolides are also highly active against Legionella pneumophila, Mycoplasma pneumoniae and Chlamydia pneumoniae (SCORNEAUX and SHRYOCK, 1999; DAVIS, 2001; HEALY, 2007). In addition to their antibacterial activity, macrolides have immunomodulatory properties. Their effect is dependent on how long and in what dosage they are applied; in short-term treatment they enhance the immune response, while in long-term treatment, at sub-threshold concentrations, they can induce immunosuppression (PASQUALE and TAN, 2005). Use of this group of antibiotics weakens the inflammatory reaction by inhibiting production of IL-1, IL-2 and TNF $\alpha$. Moreover, they modify the activity of immune cells by altering their functions in phagocytic processes (CAO et al., 2006; SHINKAI et al., 2008).

Due to their wide range of activity, macrolides have found application in the treatment of many illnesses in humans and animals, including acute and chronic inflammatory states in the respiratory system, such as atypical pneumonia and pertussis, infections of the digestive tract induced by Campylobacter jejuni/coli, genitourinary infections, and streptococcal infections, as well as in eradication of Helicobacter pylori (DAVIS, 2001; HEALY, 2007). Moreover, macrolides attain a 10 -fold higher concentration in lung tissue than in blood plasma, which is exploited in the treatment of respiratory diseases (CHIN et al., 1998 and 2000; LOPEZ-BOADO and RUBIN, 2008). In cattle, macrolides - mainly tylosin, tilmicosin and roxithromycin - have found application in the treatment of respiratory infections induced by Mannheimia haemolytica, Pasteurella spp., Klebsiella spp., $H$. somni and Mycoplasma. In the United States and Canada these antibiotics have been used in metaphylaxis for bovine respiratory disease complex (BRDC) (BOOKER et al., 2007).

In view of the widespread use of macrolides in treatment and metaphylaxis for bovine respiratory syndrome, and the variations in their effect on defence mechanisms, depending on the age of the animals, the aim of the study was to evaluate the effect of tylosin, tilmicosin and roxithromycin on viability, apoptosis and oxidative stress in bovine leukocytes in in vitro conditions.

\section{Material and methods}

The material for the study consisted of blood collected into EDTA tubes from the external jugular vein of Holstein-Friesian cattle, total $n=60$, aged 1 week to 2 years, during routine veterinary examinations (each group $n=15$ : group 1 - calf $<1$ month, group 2- $>1$ month and $<5$ months, group 3 - calves between 6 and 9 months, group $4->12$ months). It should be noted that no examined animal showed any clinical signs of disease.

Cell isolation. Leukocytes were isolated from the whole blood by density gradient separation using Histopaque 1083, according to the method described by HALLIDAY et 


\section{R. Urban-Chmiel et al.: Macrolides effect on leukocytes}

al. (2005). The cell suspension obtained, with a density of $5 \times 10^{6}$, was suspended in RPMI 1640 medium with 7\% FBS, penicillin G $(100 \mathrm{U} / \mathrm{mL})$ and streptomycin $(100 \mu \mathrm{g} / \mathrm{mL})$.

Preparation of cell cultures. The cells were cultured in 24-well plates (NUNC, Ge) in RPMI 1640 medium with 7\% FBS, according to the method described by URBANCHMIEL et al. (2009). A cell suspension at a concentration of $2.5 \times 10^{6} / \mathrm{mL}$ was added in the amount of $500 \mu \mathrm{L}$ to each well containing $500 \mu \mathrm{L}$ RPMI 1640. Then solutions of tylosin $(80 \mu \mathrm{g} / \mathrm{mL})$, tilmicosin $(5 \mu \mathrm{g} / \mathrm{mL})$ and roxithromycin $(10 \mu \mathrm{g} / \mathrm{mL})$ were added in the amount of $100 \mu \mathrm{L}$ to each well. The control consisted of a leukocyte culture in RPMI 1640 medium. The plate was incubated for $24 \mathrm{~h}$ at $37^{\circ} \mathrm{C}$ in an atmosphere with $5 \% \mathrm{CO}_{2}$ (KADOTA et al., 2005; LEE et al., 2004). The concentrations of antibiotics were adapted to the therapeutic doses of each.

Leukocytes viability. The viability of the cells was evaluated immediately after isolation and following 24-hour incubation in RPMI 1640 with the antibiotics tested. The viability percentage was determined by the trypan blue test (Sigma, Ge) according to the method described by SIKORA (1996), and by flow cytometry of cells stained with propidium iodide in a flow cytometer (Epics XL Beckman-Coulter, Comesa CH-Werfen Company, USA) at $488 \mathrm{~nm}$ (1999).

Nitro blue tetrazolium reduction (NBT) assay. The metabolic activity of the cells was determined by nitro blue tetrazolium reduction (NBT) assay according to the method described by PICK (1986). A suspension of a 24-hour leukocyte culture was dispensed in the amount of $100 \mu \mathrm{L}$ into each well of a 96-well plate and incubated for $10 \mathrm{~min}$. at $37{ }^{\circ} \mathrm{C}$. Then $100 \mu \mathrm{L}$ of NBT solution $(1 \mathrm{mg} / \mathrm{mL})$ suspended in HBSS and $100 \mu \mathrm{L}$ of iodoacetamide were added. An absorbance was read with a microplate reader (BioRad, model 680, PL) at $550 \mathrm{~nm}$ following $90-\mathrm{min}$ incubation at $37^{\circ} \mathrm{C}$ in an atmosphere with $5 \% \mathrm{CO}_{2}$.

Determination of the concentration of NO free radicals. The NO production ions was determined in terms of nitrite ion as nitric oxide produced would be rapidly converted to nitrite ion (CHUI et al., 2004). The concentration of nitrate ions was determined using Griess reagent (Sigma, Ge). The Content of nitrate ions released from the cells following incubation with the antibiotics was determined in a Griess reaction, according to the method described by MISKO et al. (1993). Fifty $\mu \mathrm{L}$ of cell suspension and $50 \mu \mathrm{L}$ of Griess reagent (Sigma) were dispensed into each well of a 96-well microplate. The plates were incubated for $15 \mathrm{~min}$. at $37^{\circ} \mathrm{C}$. Absorbance was read in a microplate reader (BioRad, model $680, \mathrm{PL}$ ) at $540 \mathrm{~nm}$. A standard curve was prepared, based on a series of dilutions $\left(\mathrm{NaNO}_{2}\right.$, Sigma). The result was expressed in $\mathrm{mM} / \mathrm{L}$.

Leukocyte apoptosis evaluation. Apoptotic cells were identified using a FITC Annexin V Apoptosis Detection Kit I (BD Pharmingen ${ }^{\mathrm{TM}}$ ) according to the procedure recommended by the manufacturer. Annexin and propidium iodide, in the amount of 5 


\section{R. Urban-Chmiel et al.: Macrolides effect on leukocytes}

$\mu \mathrm{l}$ each, were added to a 24-hour cell culture suspended in $10 \mathrm{x}$ Annexin V Binding Buffer. The samples were incubated at room temperature without access to light for 15 min. Cytometric analysis was performed at $488 \mathrm{~nm}$ after adding $400 \mu \mathrm{L} 10 \mathrm{x}$ Annexin V Binding Buffer to each sample.

Chemotactic activity determination. The chemotactic activity of the neutrophils was determined using a 48-well Boyden chamber (R\&D Systems, USA), with a nitrocellulose membrane $3 \mu \mathrm{m}$ in diameter. A homologous serum activated with zymosan from $S$. cerevisiae was used as the chemotactic factor (Sigma, Ge). The number of migrating cells was determined in an optical microscope (Olympus, JP) at $40 \times$ magnification. The chemotactic activity (\%) when exposed to each of the antibiotics was determined according to the formula given by (ALVES et al., 1996):

$\mathrm{cf}=($ chemotactic factor-induced cell migration / spontaneous cell migration $)-1 \times 100 \%$

Statistical analysis. Statistical analysis was carried out with Statistica 10.0 (Statsoft, USA) and ANOVA (Kruskal-Wallis test) as nonparametric descriptive statistics (median, range) for dependent variables, the homogeneity of variance analysis was found using Levenea's test at a significance level of $\mathrm{P} \leq 0.05$. Correlation of the results was analysed using Pearson's coefficient.

\section{Results}

The study found that macrolides had a differential effect on the percentage of viability of the bovine leukocytes (Table 1). All the antibiotics tested reduced the viability of leukocytes obtained from calves up to 1 month. In the case of the leukocytes obtained from calves $<1$ month old the percentage of viability was on a similar level, at between $96.5 \%$ and $98 \%$. Each tested antibiotic reduced the leukocyte viability for each group of calves when compared to the control. The lowest viability was noted in leukocytes incubated with tylosin, however this result was not statistically significant. In the culture of leukocytes isolated from calves aged $<1$ month and $>12$ months old, viability following incubation with the antibiotics was reduced to $85.4-88.1 \%$. The lowest viability was observed in leukocytes incubated with roxithromycin.

The viability of leukocytes isolated from cattle aged from 6 to 9 months, and incubated with macrolides, was reduced to values ranging from $92.3 \%$ to $93.8 \%$. The most severe negative affect was observed following incubation with tilmicosin. However the viability $(92.3 \%)$ was not statistically significant with respect to the control. The viability percentage of the leukocytes obtained from cattle aged over one year was similar to the control or slightly decreased (Table 1). 


\section{R. Urban-Chmiel et al.: Macrolides effect on leukocytes}

Table 1. The percent of viability of leukocytes isolated from cattle of different ages following 24hour incubation with antibiotics (Average \pm SD)

\begin{tabular}{|c|c|c|c|c|}
\hline $\begin{array}{c}\text { Age of calves } \\
\text { in months }\end{array}$ & Control & Tylosin & Tilmicosin & Roxithromycin \\
\hline$<1$ & $98 \pm 3.1$ & $96.5 \pm 5.9$ & $97.5 \pm 4.2$ & $97.5 \pm 4.2$ \\
\hline$>1-5$ & $89.8 \pm 7$ & $88.1 \pm 6.9$ & $85.4 \pm 10.2$ & $84.9 \pm 12.3$ \\
\hline $6-9$ & $95.2 \pm 1.1$ & $93.8 \pm 2.0$ & $92.3 \pm 1.5$ & $92.7 \pm 1.7$ \\
\hline$>12$ & $95.9 \pm 2.2$ & $93.9 \pm 1.0$ & $94.8 \pm 0.4$ & $95.7 \pm 1.3$ \\
\hline
\end{tabular}

Analysis of the viability of particular leukocyte fractions revealed substantial variations in the percentage of live cells among lymphocytes, monocytes and neutrophils. Lymphocytes were found to be most resistant to the effects of macrolides, with viability of $91.9-99.2 \%$ in all examined groups of calves. The lowest viability was observed in the lymphocytes isolated from calves aged over 1 month and up to 5 months old, incubated with tilmicosin, while the highest viability was noted for the cells isolated from calves < 1 month and incubated with the same antibiotic. The values obtained were not statistically significant with respect to the control (Table 2). In the case of monocytes, the greatest decrease in viability (to $42.7 \%$ ) was observed in the cells obtained from cattle aged from $>1-5$ months of age and incubated with tylosin, while the highest viability (91\%) was noted in monocytes obtained from the youngest calves and incubated with roxithromycin and tilmicosin. The values obtained were not statistically significant with respect to the control (Table 2). In the case of the neutrophils, the highest viability was observed in the cells obtained from calves up to 1 month of age and treated with roxithromycin $-86.4 \%$, while the lowest viability was noted in the cells obtained from the oldest animals and incubated with tylosin. The average values for live neutrophils in all the examined groups of calves were $\geq 70 \%$, and they were not statistically significantly different with respect to the control (Table 2).

The average absorbance in the NBT test for leukocytes isolated from cattle of different ages ranged from 0.14 to 0.17 . The greatest decrease in absorbance was observed in the case of leukocytes from calves aged more than 1 month and up to 5 months, incubated with tilmicosin (0.139) and roxithromycin (0.14). However the results obtained were not statistically significant (Fig. 1).

Significant correlations were found between the metabolic activity of the leukocytes and the antibiotic applied. The correlation coefficients for NBT assay were higher than $r=0.5$. The strongest correlation was observed between the leukocytes incubated with roxithromycin and tilmicosin $(r=0.99)$ in the group of calves older than 1 month and up to 5 months old, and cells incubated with tylosin and tilmicosin in the calves aged up to one month (Table 3). 
R. Urban-Chmiel et al.: Macrolides effect on leukocytes

Dot-plot: NBT vs. age

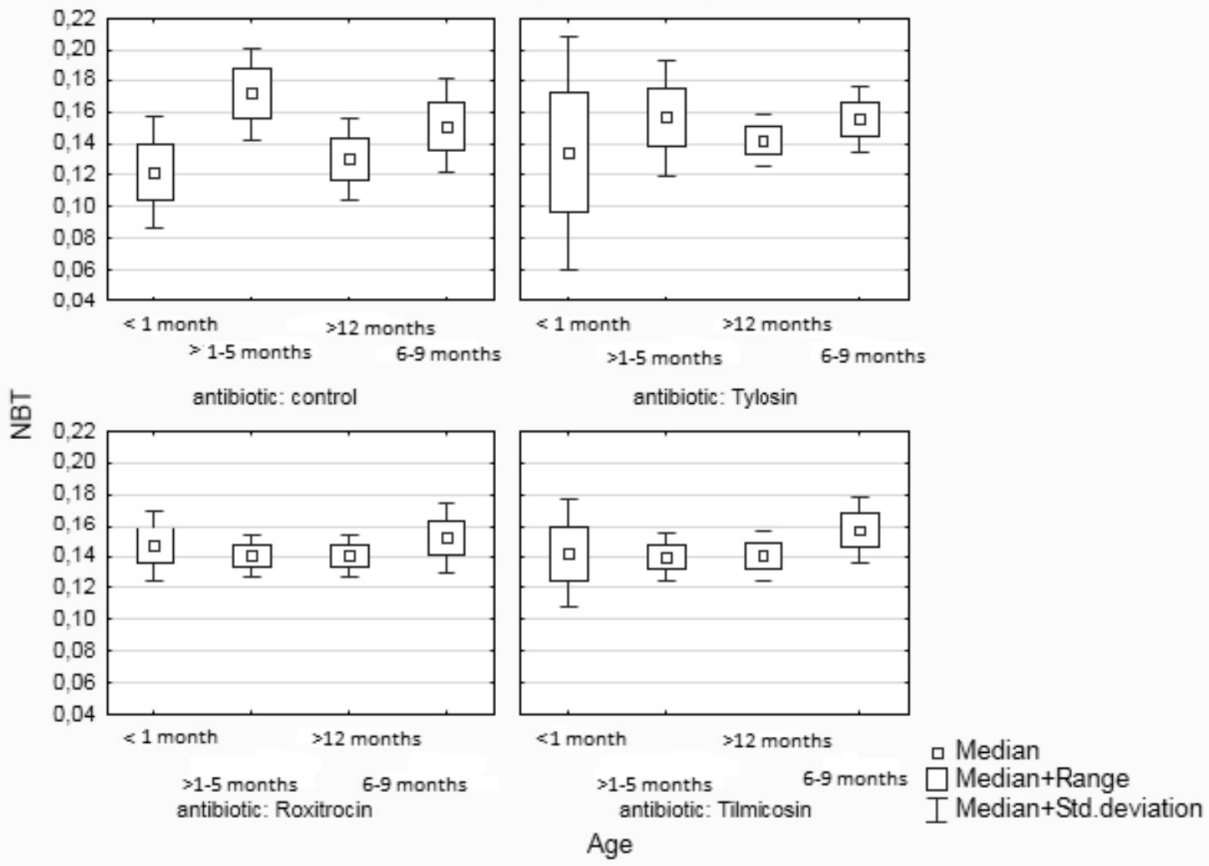

Fig. 1. The average NBT absorbance values in the leukocytes isolated from each age groups of the calves after different macrolide treatments in vitro

Table 2. The average viability (\%) of different fractions of leukocytes isolated from cattle of different ages following 24-hour incubation with antibiotics (Average \pm SD)

\begin{tabular}{|c|c|c|c|c|c|c|c|c|c|c|c|c|}
\hline & \multicolumn{3}{|c|}{ Control } & \multicolumn{3}{c|}{ Tylosin } & \multicolumn{3}{c|}{ Tylmicosin } & \multicolumn{3}{|c|}{ Roxithromycin } \\
\cline { 2 - 14 } & $\mathrm{L}$ & $\mathrm{M}$ & $\mathrm{N}$ & $\mathrm{L}$ & $\mathrm{M}$ & $\mathrm{N}$ & $\mathrm{L}$ & $\mathrm{M}$ & $\mathrm{N}$ & $\mathrm{L}$ & $\mathrm{M}$ & $\mathrm{N}$ \\
\hline \multirow{2}{*}{$\mathrm{I}$} & 99.5 & 93.5 & 75.5 & 96.9 & 88 & 85.6 & 99.2 & 91 & 82.4 & 98 & 91 & 86.4 \\
& \pm 0.9 & \pm 10 & \pm 10.5 & \pm 5.8 & \pm 17 & \pm 3.8 & \pm 1.2 & \pm 16 & \pm 18.4 & \pm 1.2 & \pm 16.2 & \pm 20.4 \\
\hline \multirow{2}{*}{ II } & 96.9 & 76.0 & 78.6 & 95.1 & 42.7 & 69.4 & 91.9 & 75.5 & 77.8 & 94.9 & 75.5 & 76.5 \\
& \pm 2.5 & \pm 28 & \pm 12 & \pm 2.4 & \pm 28.6 & \pm 18.2 & \pm 8.4 & \pm 26.4 & \pm 10.7 & \pm 4.5 & \pm 14.2 & \pm 15 \\
\hline \multirow{2}{*}{ III } & 98.3 & 75.1 & 77.5 & 98 & 64.8 & 77.8 & 97.7 & 61.8 & 70.3 & 98.3 & 63.4 & 77.3 \\
& \pm 0.6 & \pm 11 & \pm 9 & \pm 0.9 & \pm 15.9 & \pm 6 & \pm 1 & \pm 14.6 & \pm 7.6 & \pm 0.4 & \pm 11.6 & \pm 7 \\
\hline \multirow{2}{*}{ IV } & 94.1 & 89.8 & 76.7 & 97.9 & 82.8 & 65.9 & 97.9 & 86.9 & 69.2 & 98.4 & 88 & 74.8 \\
& \pm 5.3 & \pm 12 & \pm 11 & \pm 0.4 & \pm 4.7 & \pm 4.6 & \pm 0.8 & \pm 5 & \pm 5.7 & \pm 0.5 & \pm 3.8 & \pm 8 \\
\hline
\end{tabular}

I - calves $<1$ month; II - calves $>1-5$ months; III - young cattle between 6-9 months; IV - cattle $>1$ year; L lymphocytes; $\mathrm{M}$ - monocytes; $\mathrm{N}$ - neutrophils 


\section{R. Urban-Chmiel et al.: Macrolides effect on leukocytes}

Analysis of the content of NO ions did not reveal significant changes in the ion concentration in cells incubated with antibiotics. The values obtained for leukocytes in all experimental groups of calves were at a similar level and ranged from $2.14 \mathrm{mM} / 1$ in the control group (calves aged $>1-5$ months) to $3.3 \mathrm{mM} / 1$ for the leukocytes isolated from the oldest group of animals, treated with roxithromycin (Fig. 2). The concentration of NO in the youngest group of animals ranged from $2.6 \mathrm{mM} / 1$ for leukocytes treated by tylosin to $2.9 \mathrm{mM} / 1$ for leukocytes treated by tilmicosin. The greatest decrease in NO was observed in the leukocytes incubated with tylosin isolated from calves aged $>1-5$ months and those 6-9 months old (Fig. 2).

Table 3. Correlation coefficients of metabolic activity of leukocytes isolated from each age group of the calves

\begin{tabular}{|c|c|c|c|c|c|c|c|c|c|c|c|c|}
\hline & \multicolumn{3}{|c|}{ Calves $<1$ month } & \multicolumn{3}{|c|}{ Calves $>1-5$ months } & \multicolumn{3}{|c|}{ Cattle $6<9$ months } & \multicolumn{3}{|c|}{ Cattle $>12$ months } \\
\hline & $\mathrm{T}$ & $\mathrm{Tl}$ & $\mathrm{R}$ & $\mathrm{T}$ & $\mathrm{Tl}$ & $\mathrm{R}$ & $\mathrm{T}$ & $\mathrm{Tl}$ & $\mathrm{R}$ & $\mathrm{T}$ & $\mathrm{Tl}$ & $\mathrm{R}$ \\
\hline $\mathrm{C}$ & 0.88 & 0.86 & 0.31 & -0.77 & -0.49 & -0.5 & $0.96^{\mathrm{a}}$ & 0.86 & 0.81 & -0.74 & 0.09 & -0.11 \\
\hline $\mathrm{T}$ & - & $0.99^{\mathrm{a}}$ & -0.17 & - & 0.92 & 0.92 & - & $0.94^{\mathrm{a}}$ & 0.82 & - & 0.59 & 0.74 \\
\hline $\mathrm{Tl}$ & $0.99^{\mathrm{a}}$ & - & -0.19 & 0.92 & - & $0.99^{\mathrm{a}}$ & $0.94^{\mathrm{a}}$ & - & $0.93^{\mathrm{a}}$ & 0.59 & - & 0.97 \\
\hline $\mathrm{R}$ & -0.17 & -0.19 & - & 0.92 & $0.99^{\mathrm{a}}$ & - & 0.82 & $0.93^{\mathrm{a}}$ & - & 0.74 & 0.97 & - \\
\hline
\end{tabular}

$\mathrm{C}$ - control; $\mathrm{T}$ - culture with tylosin; $\mathrm{Tl}$ - culture with tilmicosin; R - culture with roxithromycin; ${ }^{\circ}$ significant values $(\mathrm{P} \leq 0.05)$

Substantial correlations were observed between NO concentration in the cells and the antibiotic applied. The correlation coefficients were at a level of $r \geq 0.5$, with the strongest correlation observed in the case of leukocytes incubated with tilmicosin $(r=0.9)$.

The experiment showed that the macrolides tested had a significant effect on induction of apoptosis in the bovine leukocytes. The lowest percentage of apoptotic cells $(2.1 \%)$ was observed in the cells isolated from the youngest calves after incubation with roxithromycin. This value was significant $(\mathrm{P} \leq 0.05)$ in comparison to the control and the other groups of calves. The greatest number of apoptotic cells was observed following incubation with tilmicosin, and the values obtained were statistically significant different $(\mathrm{P} \leq 0.05)$ in comparison to the control, in calves aged up to 1 month, $>1-5$ and $>12$ months old (Fig. 3). The analysis of variances showed significant differences $(\mathrm{P} \leq 0.05)$ in the obtained results between the leukocytes obtained from different age groups of calves after roxithromycin treatment (Fig. 3).

Analysis of the effect of the antibiotics tested on the chemotaxis of the leukocytes revealed a reduction in chemotactic activity, irrespective of the age of the cattle. The average chemotactic activity for the leukocytes incubated with antibiotics ranged from $49 \%$ to $76.3 \%$. The highest, significant $(\mathrm{P} \leq 0.05)$ decrease in migration was observed in the case of cells isolated from calves aged $>1-5$ months old and incubated with tylosin. 
Dot-plot: NO vs. age
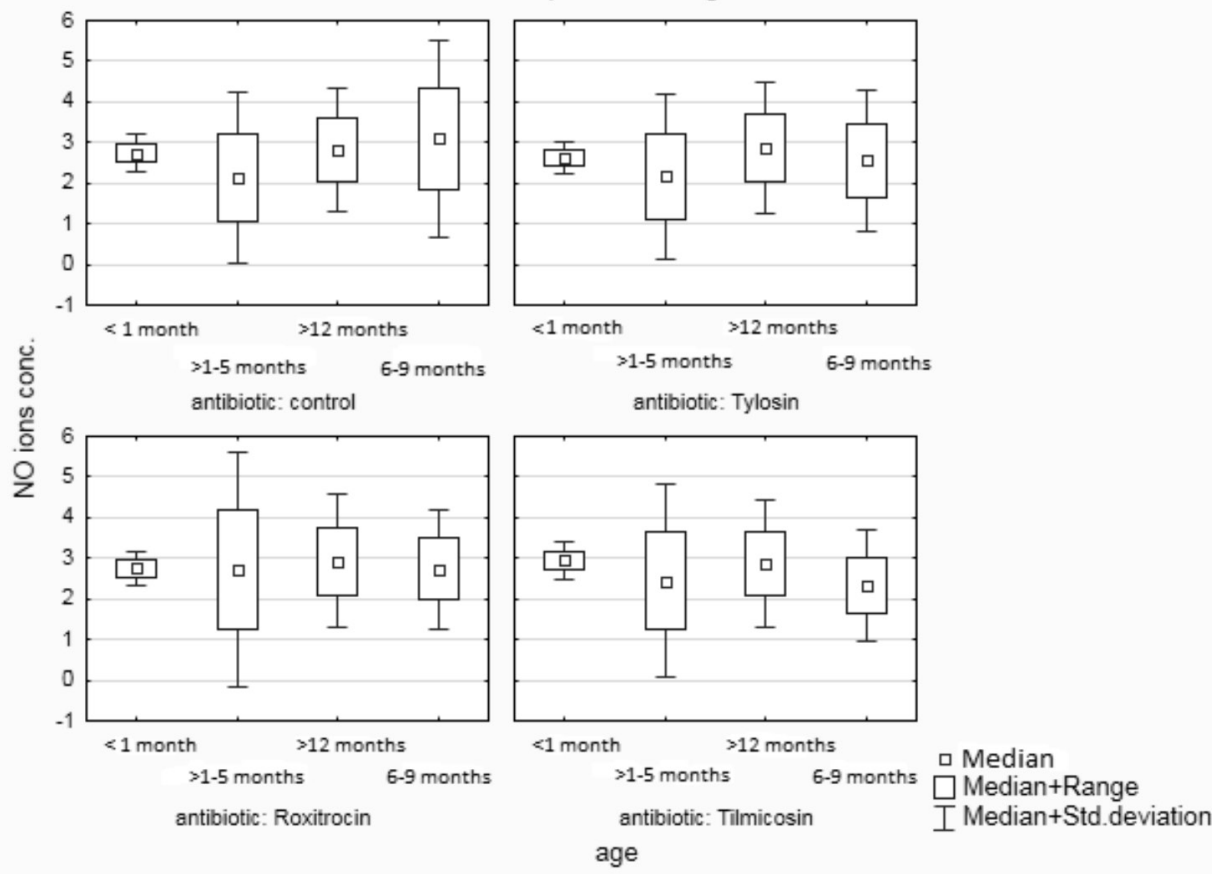

Fig. 2. The average NO ion concentration values in the leukocytes isolated from each age group of calves after different macrolide treatments in vitro

The smallest difference in chemotaxis, in comparison with the control, was observed in the case of leukocytes isolated from young cattle aged 6-9 months old and incubated with tylosin or tilmicosin (Fig. 4).

Analysis of the correlation coefficients between the chemotactic activity of the leukocytes and the type of antibiotic applied showed significant relationships in all of the groups (Table 4). The strongest correlation $r=0.99$ was observed for the leukocytes isolated from calves up to 5 months old and incubated with tylosin, while the weakest correlation $(\mathrm{r}=0.06)$ was noted in the leukocytes isolated from calves older than 1 year and incubated with tilmicosin and tylosin (Table 4). 
R. Urban-Chmiel et al.: Macrolides effect on leukocytes

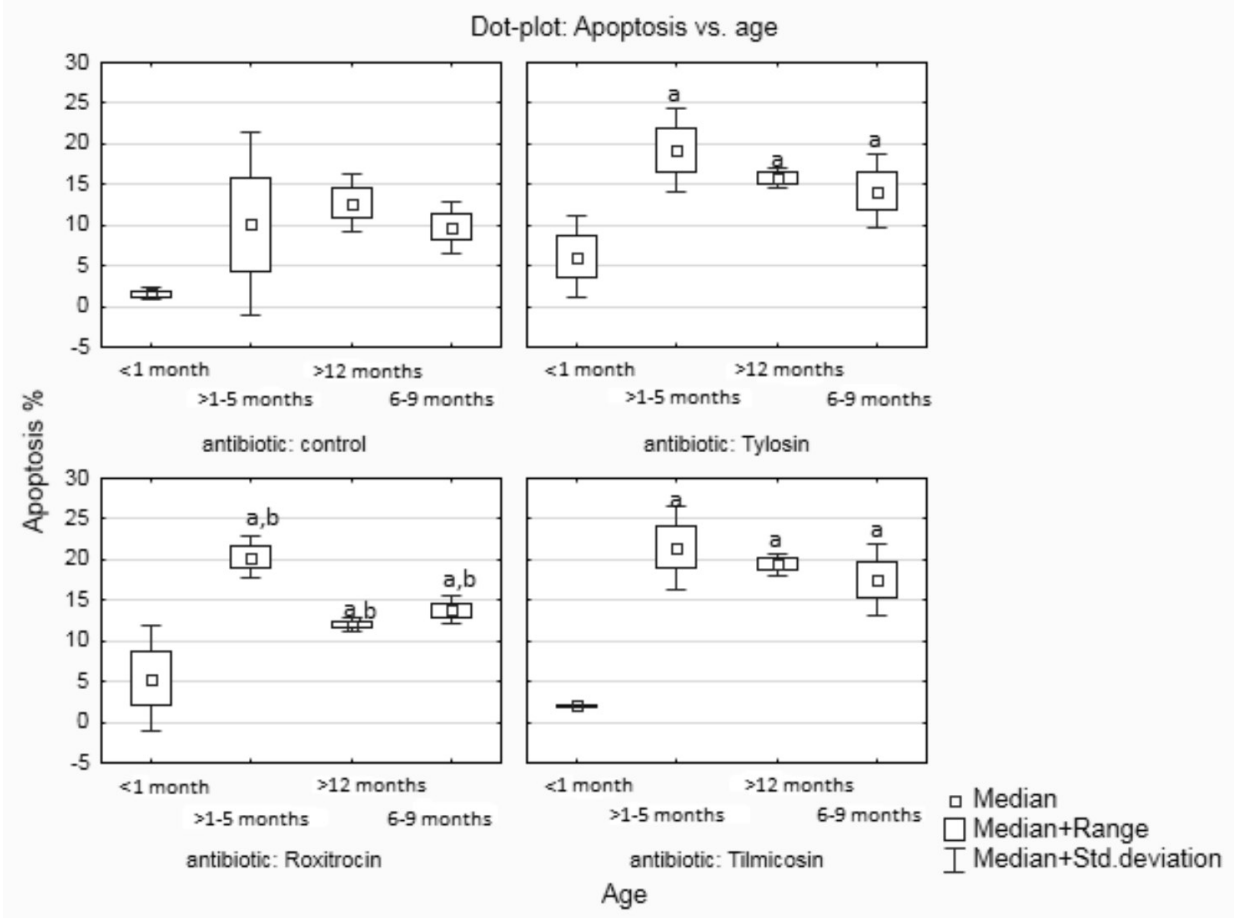

Fig. 3. The average percent of poptosis of leukocytes isolated from each age group of calves after different macrolide treatments in vitro. ${ }^{a}$ significant differences $(\mathrm{P} \leq 0.05)$ in comparison to control; ${ }^{\mathrm{b}}$ significant differences $(\mathrm{P} \leq 0.05)$ in comparison to the other groups of calves

Table 4. Correlation coefficients of chemotactic indices for the leukocytes isolated from each age group of the calves

\begin{tabular}{|c|c|c|c|c|c|c|c|c|c|c|c|c|}
\hline & \multicolumn{3}{|c|}{ Calves $<1$ month } & \multicolumn{3}{|c|}{ Calves 1-5 months } & \multicolumn{3}{|c|}{ Cattle 6-9 months } & \multicolumn{3}{|c|}{ Cattle $>12$ months } \\
\hline & $\mathrm{T}$ & $\mathrm{Tl}$ & $\mathrm{R}$ & $\mathrm{T}$ & $\mathrm{Tl}$ & $\mathrm{R}$ & $\mathrm{T}$ & $\mathrm{Tl}$ & $\mathrm{R}$ & $\mathrm{T}$ & $\mathrm{Tl}$ & $\mathrm{R}$ \\
\hline $\mathrm{C}$ & -0.91 & -0.21 & 0.99 & $0.99^{\mathrm{a}}$ & 0.29 & 0.08 & 0.3 & -0.11 & -0.26 & 0.94 & -0.26 & 0.65 \\
\hline $\mathrm{T}$ & - & 0.59 & -0.87 & - & 0.24 & 0.13 & - & 0.87 & 0.47 & - & 0.06 & 0.86 \\
\hline $\mathrm{Tl}$ & 0.59 & - & -0.12 & 0.24 & - & -0.92 & 0.87 & - & 0.79 & 0.06 & - & 0.55 \\
\hline $\mathrm{R}$ & -0.87 & -0.12 & - & 0.13 & -0.92 & - & 0.47 & 0.79 & - & 0.86 & 0.55 & - \\
\hline
\end{tabular}

$\mathrm{C}$ - control; $\mathrm{T}$ - culture with tylosin; $\mathrm{Tl}$ - culture with tilmicosin; R - culture with roxithromycin; ${ }^{\text {a statistically }}$ significant values $(\mathrm{P} \leq 0.05)$ 


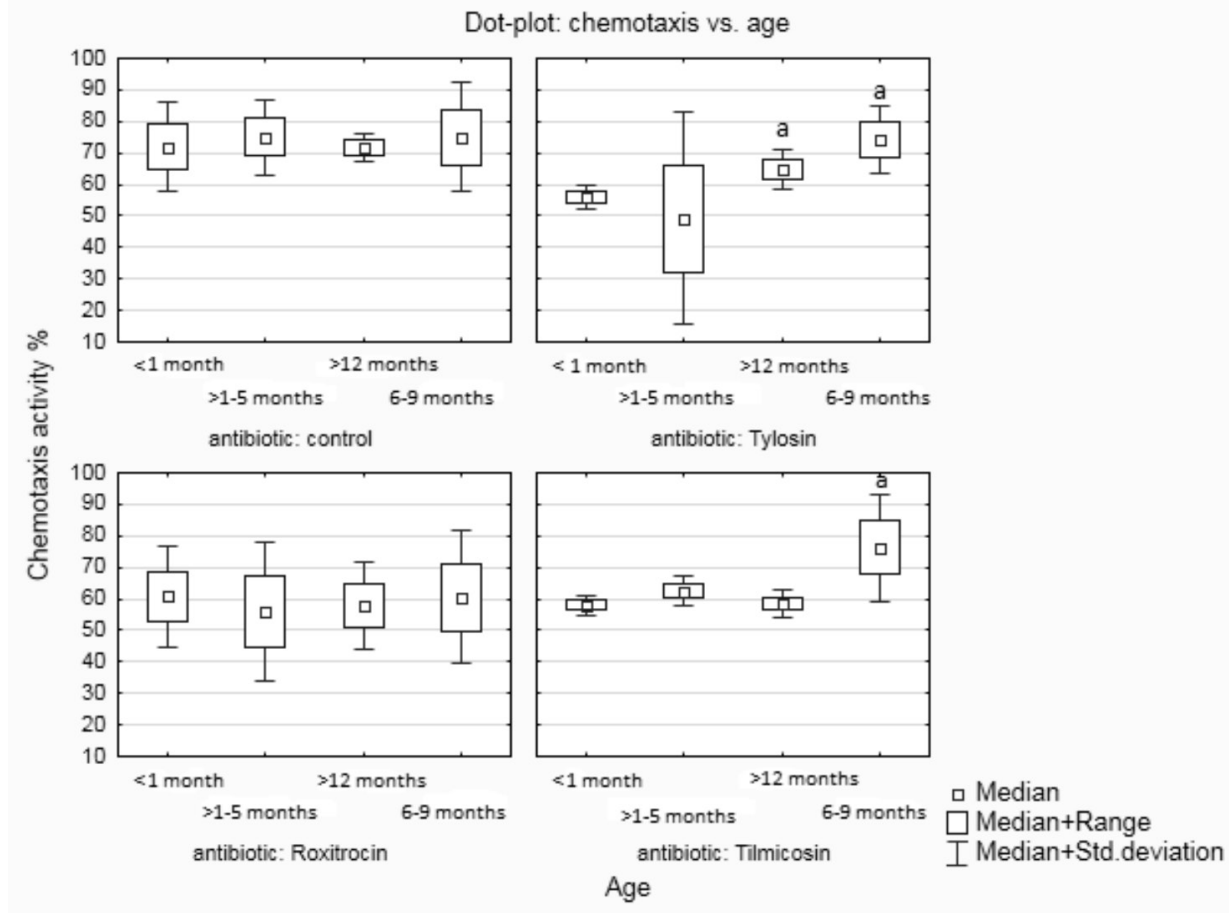

Fig. 4. Chemotaxis activity in the leukocytes in vitro in different age groups of calves after different macrolide treatments. ${ }^{a}$ Significant differences $(\mathrm{P} \leq 0.05)$ in comparison to control; ${ }^{\mathrm{b}}$ significant differences $(\mathrm{P} \leq 0.05)$ in comparison to the other groups of calves.

\section{Discussion}

The study demonstrated the varied effects of tylosin, tilmicosin and roxithromycin on viability, apoptosis, oxidative stress, intracellular metabolism and chemotactic activity of leukocytes isolated from cattle of different ages. The results obtained also indicated the slight, negative effect of these macrolides on the viability of the leukocytes. The results confirmed the ability of macrolides to induce apoptosis in leukocytes in vitro. In comparison with the control, the percentage increase in the average number of apoptotic cells in the presence of the antibiotics was about $5 \%$. The experiment also showed that among the macrolides investigated, tilmicosin exhibited the strongest apoptosis-inducing effect. The most resistant cells were the leukocytes obtained from the youngest calves, i.e. those up to 30 days old, while the highest susceptibility was noted in cells obtained from cattle up to 5 months of age. This is confirmed by other research (VAN OOSTVELDT et 
al., 1999; CHIN et al., 2000; KOCH et al., 2000) on human leukocytes treated with macrolide antibiotics. Similar observations have been reported for tilmicosin, which also promotes neutrophil apoptosis (LEE et al., 2004).

The inhibitory effect of macrolides on the level of oxidative stress in bovine leukocytes may also be seen in the results of the NBT test, which indirectly indicated a reduction in intracellular oxidative stress, expressed as a decrease in the production and release of free radicals. The results also confirm the significant effect of the antibiotics on the metabolism of bovine leukocytes. The strongest inhibitory effect was noted in the case of incubation with roxithromycin and tilmicosion, which has also been confirmed in studies on leukocytes isolated from humans and rodents (KOCH et al., 2000; KOHRI et al., 2000). Other authors (WALES and WOODHEAD, 1999; ESFANDIARI et al., 2003; CZECZOT et al., 2005; HALLIDAY et al., 2005) report that macrolide antibiotics exhibit activity inhibiting oxidative bursts in immune cells, which is included among their antiinflammatory properties.

Analysis of the intensity of oxidative stress, and the changes in the intracellular metabolism of the leukocytes treated with macrolides, indicates that roxithromycin has the least harmful effect. This antibiotic was also found to have the strongest inhibitory effect on the chemotaxis of the leukocytes, in comparison with tylosin and tilmicosin, which is highly beneficial in reducing the inflammatory process in the first phase of a disease (LEE et al., 2004). This is a desirable effect for reducing clinical symptoms associated with the respiratory system, i.e. dyspnoea, cough, and accumulation of exudate in the pulmonary alveoli, which eliminates the development of the disease. This antibiotic, belonging to the latest generation of chemotherapeutic agents, could be used in both the treatment and metaphylaxis of disease complexes in farm animals, as well as tilmicosin or tylosin (NOYES et al., 2015).

The results obtained show that the macrolides had a slight influence on production of nitrate ions, which is indicated by the substantial decrease in their concentration in the leukocyte cultures with the selected antibiotics. Similar results were reported by other researchers (CAO et al., 2006), who obtained a reduction in the production and release of NO ions by murine leukocytes following incubation with tilmicosin or tylosin. Another study (IANARO et al., 2000) also demonstrated a reduction in the synthesis of nitrogen oxides by murine macrophages incubated with roxithromycin.

The inhibition of the production and release of NO ions and the metabolic activity of immune cells, confirmed by the NBT test, substantiates the expediency of using this group of antibiotics to treat respiratory disease, particularly in the early stage of the disease process. 


\section{R. Urban-Chmiel et al.: Macrolides effect on leukocytes}

\section{Conclusion}

To sum up, the results obtained indicate that all of the macrolide antibiotics investigated exhibit a modulatory effect on the functions of leukocytes isolated from cattle of different ages. The strongest inhibitory effect on the metabolic activity and chemotaxis of the leukocytes was exhibited by roxithromycin, which at the same time had the least harmful effect on the leukocytes.

\section{References}

ALVES, A. C., A. L. A. PIRES, H. N. CRUZ, M. F. SERRA, B. L. DIAZ, R. S. B. CORDEIRO, V. LAGENTE, M. A. MARTINS, P. M. R. SILVA (1996): Selectitve inhibition of phosphodiesterase type IV suppresses the chemotactic resonsiveness of rat eosinophilis in vitro. Eur. J. Pharmacol. 312, 89-96.

BOOKER, C. W., S. M. ABUTARBUSH, O. C. SCHUNICHT, G. K. JIM, T. PERRETT, B. K. WILDMAN, P. T. GUICHON, T. J. PITTMAN, C. JONES, C. M. POLLOCK (2007): Evaluation of the efficacy of tulathromycin as metaphylactic antimicrobial in feedlot calves. Vet. Therapy 8, 183-200.

CAO, X. Y., M. DONG, J. Z. SHEN, B. B. WU, C. M. WU, X. D. DU, Z. WANG, Y. T. QI, B. Y. LI (2006): Tilmicosin and tylosin have antiinflammatory properties via modulation of COX2 and iNOS gene expression and production of cytokines in LPS-induced macrophages and monocytes. Int. J. Antimicrob. Agents 27, 431-438.

CHIN, A. C., D. W. MORCK, J. K. MERRILL, H. CERI, M. E. OLSON, R. R. READ, P. DICK, A. G. BURET (1998): Anti-inflammatory benefits of tilmicosin in calves with $P$. haemolytica-infected lungs. Am. J. Vet. Res. 59, 765-771.

CHIN, A., W. D. LEE, K. A. MURRIN, D. W. MORCK, J. K. MERRILL, P. DICK, A. G. BURET (2000): Tilmicosin induces apoptosis in bovine peripheral neutrophils in the presence or in the absence of Pasteurella haemolytica and promotes neutrophil phagocytosis by macrophages. Antimicrob. Agents Chem. 44, 2465-2470.

CHUI, C. H., J. C. ON TANG, F. Y. LAU, I. T. N. TEO, M. Y. C. YAU, R. S. M. WONG, G. Y. M. CHENG, S. K. W. HO, T. W. T. LEUNG, K. S. HUI, M. M. WONG, S. FATIMA, C. H. CHENG, F. CHEUNG, W. Q. TAN, L. M. C CHOW, D. GUO, A. S. C. CHAN (2004): Gleditsia sinensis fruit extract induced growth inhibition involves basic fibroblast growth factor and nitric oxide. Int. J. Mol. Med. 13, 169-173.

CZECZOT, H., M. SKRZYCKI, D. ŚCIBIOR, M. PODSIAD (2005): Aktywność izoenzymów dysmutazy ponadtlenkowej u chorych z nowotworami przewodu pokarmowego. Adv. Clin. Exp. Med. 14, 731-737.

ESFANDIARI, N., R. K. SHARMA, R. A. SALEH, A. J. THOMAS, L. AGARVAL (2003): Utility of the nitroblue tetrazolium reduction test for assessment of reactive oxygen species production by seminal leukocytes and spermatozoa. J. Androl. 24, 862-870.

DAVIS, S. (2001): Macrolides and ketolides: more than just antimicrobials. Pharmacol. J. 78, 24-27. 
HALLIDAY, S., F. HOUSTON, N. HUNTER (2005): Expression of $\mathrm{Pr}^{\mathrm{PC}}$ on cellular components of sheep blood. J. Gen. Virol. 86, 1571-1579.

HEALY, D. P. (2007): Macrolide immunomodulation of chronic respiratory diseases. Curr. Infect. Dis. Rep. 9, 7-13.

IANARO, A., A. IALENTI, P. MAFFIA, L. SAUTEBIN, L. ROMBOLÀ, R. CARNUCCIO, T. IUVONE, F. D’ACQUISTO, M. DI ROSA (2000): Anti-inflammatory activity of macrolide antibiotics. J. Pharmacol. Exp. Therap. 292, 156-163.

KADOTA, J. I., S. MIZUNOE, K. KISHI, I. TOKIMATSU, H. NAGAI, M. NASU (2005): Antibiotic induced apoptosis In human activated peripheral lymphocytes. Int. J. Antimic. Agents 25, 216-220.

KOCH, C. C., D. J. ESTEBAN, A. C. CHIN, M. E. OLSON, R. R. READ, H. CERI, D. W. MORCK, A. G. BURET (2000): Apoptosis, oxidative metabolism and interleukin-8 production in human neutrophils exposed to azithromycin: effects of Streptococcus pneumonia. J. Antimicrob. Chemotherapy 46, 19-26.

KOHRI, K., J. TAMAOKI, M. KONDO, K. AOSHIBA, E. TAGAYA, A. NAGAI (2000): Macrolide antibiotics inhibit nitric oxide generation by rat pulmonary alveolar macrophages. Europ. Resp. J. 15, 62-67.

LEE, W. D., A. N. FLYNN, J. M. LEBLANC, J. K. MERRILL, P. DICK, D. W. MORCK, A. G. BURET (2004): Tilmicosin-induced bovine neutrophil apoptosis is cell-specific and downregulates spontaneous $\mathrm{LTB}_{4}$ synthesis without increasing Fas expression. Vet. Res. 35, 213-224.

LOPEZ-BOADO, Y. S., B. K. RUBIN (2008): Macrolides as immunomodulatory medications for the therapy of chronic lung diseases. Curr. Opin. Pharmacol. 8, 286-291.

MISKO, T. P., R. J. SCHILLING, D. SALVEMINI, W. M. MOORE, M. G. CURRIE (1993): A fluorometric assay for the measurement of nitrite in biological samples. Anal. Biochem. 214, $11-16$.

NOYES, N. R., K. M. BENEDICT, S. P. GOW, C. W. BOOKER, S. J. HANNON, T. A. MCALLISTER, P. S. MORLEY (2015) Mannheimia haemolytica in feedlot cattle: prevalence of recovery and associations with antimicrobial use, resistance, and health outcomes. J. Vet. Intern. Med. 29, 705-713.

PASQUALE, T. R., J. S. TAN (2005): Nonantimicrobial effects of antibacterial agents. Clin. Infect. Dis. 40, 127-135.

PICK, E. (1986): Microassays for superoxide and hydrogen peroxide production and nitroblue tetrazolium reduction using an enzyme immunoassay microplate reader. Meth. Enzymol. 132, 407-413.

SCORNEAUX, B., T. R. SHRYOCK (1999): Intracellular accumulation, subcellular distribution, and efflux of tilmicosin in bovine mammary, blood, and lung cells. J. Dairy. Sci. 82, 12021212.

SHINKAI, M., M. O. HENKE, B. K. RUBIN (2008): Macrolide antibiotics as immunomodulatory medications: Proposed mechanisms of action. Pharmacol. Therap. 117, 393-405. 


\section{R. Urban-Chmiel et al.: Macrolides effect on leukocytes}

SIKORA, J. P. (1996): Chemiluminescent assessment of aerobic metabolism of peripheral blood polymorphonuclear leukocytes in children with increased susceptibility to respiratory tract infections. Centr. Eur. J. Immunol. 21, 33-38.

URBAN-CHMIEL, R., A. WERNICKI, A. PUCHALSKI, M. DEC (2009): The effect of $\alpha$-tocopherol and ascorbic acid supplementation on selected immunological parameters in bovine leukocytes in vitro. Acta Vet. Brno 78, 589-594.

VAN OOSTVELDT, K. H. DOSOGNE, C. BURVENICH, M. J. PAAPE, V. BROCHEZ, E. VAN DEN EECKHOUT (1999): Flow cytometric procedure to detect apoptosis of bovine polymorphonuclear leukocytes in blood. Vet. Immunol. Immunopathol. 70, 125-133.

WALES, D., M. WOODHEAD (1999): The anti-inflammatory effects of macrolides; Thorax 54, 58-66.

Received: 14 April 2016

Accepted: 31 August 2016

URBAN-CHMIEL, R., A. WERNICKI, U. LISIECKA, A. PUCHALSKI, M. DEC, D. STEGIERSKA, L. KUREK: Učinak odabranih makrolida na neka obilježja goveđih leukocita. Vet. arhiv 87, 571-584, 2017.

\section{SAŽETAK}

Cilj je ovog istraživanja bio procijeniti učinak tilozina, tilmikozina i roksitromicina na preživljavanje, test redukcije "nitro-tetrazol-modrog" (NBT), kemotaksiju, apoptozu i oksidacijski stres goveđih leukocita u uvjetima in vitro. Prilikom rutinskog veterinarskog pregleda, u epruvete s EDTA bila je uzeta krv iz jugularne vene goveda holštajnsko-frizijske pasmine u dobi od tjedan dana do 2,5 godine. Određen je postotak preživljavanja leukocita, koncentracija iona nitrata (NO), metabolička aktivnost (test redukcije "nitro-tetrazolmodrog", NBT), kemotaksijska aktivnost i apoptoza. Rezultati su pokazali blagi negativni učinak spomenutih makrolida na preživljavanje leukocita i potvrdili sposobnost makrolida da potaknu njihovu apoptozu in vitro te naznačuju da svi pretraženi makrolidi imaju modulacijski učinak na funkciju leukocita goveda različite dobi. Najjači inhibicijski učinak na test redukcije NBT i kemotaksiju leukocita pokazao je roksitromicin, koji je istodobno imao najmanje negativan učinak na leukocite.

Ključne riječi: apoptoza, goveđi leukociti, makrolidi, oksidacijski stres 